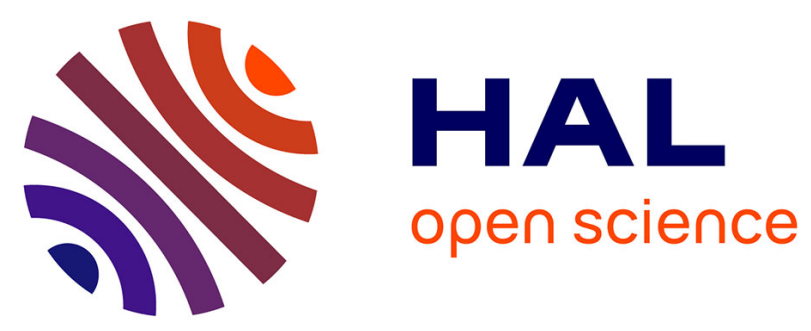

\title{
Synthesis, crystal structure, magnetic, spectroscopic, and theoretical investigations of two new nitronyl-nitroxide complexes
}

Cristian Andrei Spinu, Céline Pichon, Gabriela Ionita, Teodora Mocanu, Sergiu Calancea, Mihai Raduca, Jean-Pascal Sutter, Mihaela Hillebrand, Marius Andruh

\section{To cite this version:}

Cristian Andrei Spinu, Céline Pichon, Gabriela Ionita, Teodora Mocanu, Sergiu Calancea, et al.. Synthesis, crystal structure, magnetic, spectroscopic, and theoretical investigations of two new nitronyl-nitroxide complexes. Journal of Coordination Chemistry, 2021, 74 (1-3), pp.279-293. 10.1080/00958972.2021.1871900 . hal-03188807

\section{HAL Id: hal-03188807 https://hal.science/hal-03188807}

Submitted on 2 Apr 2021

HAL is a multi-disciplinary open access archive for the deposit and dissemination of scientific research documents, whether they are published or not. The documents may come from teaching and research institutions in France or abroad, or from public or private research centers.
L'archive ouverte pluridisciplinaire HAL, est destinée au dépôt et à la diffusion de documents scientifiques de niveau recherche, publiés ou non, émanant des établissements d'enseignement et de recherche français ou étrangers, des laboratoires publics ou privés. 


\title{
Synthesis, crystal structure, magnetic, spectroscopic, and theoretical investigations of two new nitronyl- nitroxide complexes
}

Cristian Andrei Spinu ${ }^{\mathrm{a}}$, Céline Pichon ${ }^{\mathrm{b}}$, Gabriela Ionita $^{\mathrm{c}}$, Teodora Mocanu ${ }^{\mathrm{a}, \mathrm{c}}$, Sergiu Calancea $^{\mathrm{a}, \mathrm{e}}$, Mihai Raduca ${ }^{\mathrm{a}}$, Jean-Pascal Sutter*b ${ }^{\mathrm{b}}$, Mihaela Hillebrand ${ }^{* \mathrm{f}}$ and Marius Andruh* ${ }^{\mathrm{a}}$

${ }^{a}$ Inorganic Chemistry Laboratory, Faculty of Chemistry, University of Bucharest, Str. Dumbrava Rosie 23,020464-Bucharest,Romania; e-mail: marius.andruh@dnt.ro

${ }^{b}$ Laboratoire de Chimie de Coordination du CNRS (LCC), Université de Toulouse, CNRS, Toulouse, France; e-mail: sutter@lcc-toulouse.fr

"Ilie Murgulescu" Institute of Physical Chemistry, Romanian Academy, Splaiul Independentei 202, Bucharest-060021, Romania

${ }^{e}$ Moldova State University, MD-2009-Chisinau, Faculty of Chemistry and Chemical Technology, Moldova

${ }^{f}$ Physical Chemistry Department, Faculty of Chemistry, University of Bucharest, Bd. Elisabeta 4-12, 030018-Bucharest, Romania; E-mail: mihaela.hillebrand@ gmail.com

\begin{abstract}
Two mononuclear complexes $\left[\left(\mathrm{Et}_{3} \mathrm{NH}\right)\left[\mathrm{M}(\mathrm{hfac})_{2} \mathrm{~L}\right](\mathrm{M}=\mathrm{Ni}, 1 \mathrm{Zn}, 2)\right.$ have been synthesized using a nitronyl-nitroxide radical substituted nitrophenol, i.e., 2-(2-Hydroxy-3-methoxy-5nitrophenyl)-4,4,5,5-tetramethyl-4,5-dihydro- $1 \mathrm{H}$-imidazol-3-oxide-1-oxyl, $\mathrm{HL}, \quad$ as a proligand. The crystal structures of the two compounds have been solved and indicate an octahedral coordination geometry of the metal ions. The magnetic behavior for compound 1 is characterized by a strong antiferromagnetic metal-radical interaction $\left(J=-351 \pm 1 \mathrm{~cm}^{-1} ; \boldsymbol{H}\right.$ $\left.=-J S_{\mathrm{Ni}} \boldsymbol{S}_{\mathrm{Rad}}\right)$. This exchange interaction was rationalized by DFT calculations. The EPR spectra recorded both in solution and solid state at $120 \mathrm{~K}$ confirm the $S=1 / 2$ ground state for compound 1.
\end{abstract}




\section{INTRODUCTION}

A large family of molecular magnetic materials consists of heterospin complexes generated by $d$ or $f$ metal ions and paramagnetic organic radicals acting as ligands [1]. The most popular radicals are the nitronyl-nitroxides (Nit), which are readily obtained, starting from aldehydes, following or adapting Ullman's synthetic approach [2]. The rich diversity of nitronylnitroxide ligands arises from the availability of a very large number of mono- and polyaldehydes, as well as from the possibility to decorate the nitronyl-nitroxide platform with other coordinating groups (preexisting in the staring aldehydes), which play an important role on the nuclearities and spin topologies of the resulting systems [3]. The family of magnetic materials constructed using paramagnetic organic ligands has been recently extended with polynuclear complexes containing two different metal ions, both paramagnetic [4]. Most of these heterotrispin complexes contain $3 d$ and $4 f$ metal ions. The exchange interactions between $2 p$ radicals and paramagnetic metal ions vary between large limits, from strong antiferromagnetic to strong ferromagnetic couplings, $[1,3]$ and usually the $2 p$-n $d$ couplings are stronger than those involving lanthanides. Magneto-structural studies highlight the factors influencing the nature and strength of the exchange interactions [1]. The geometric parameters, at the level of aminoxyl-metal bond, influence the orientation of the magnetic orbitals, $\pi^{*}$ (Nit) and $d$ or $f$, and, consequently, their overlap or orthogonality.

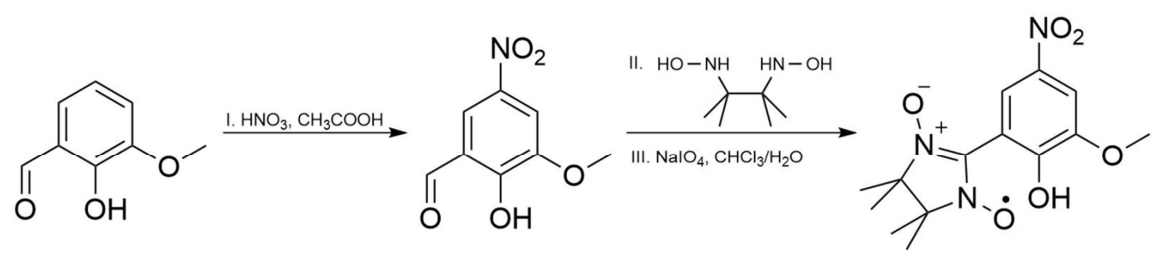

$\mathrm{HL}$

Scheme 1. Synthesis of the paramagnetic ligand.

Surprisingly, in spite of their simplicity and popularity in coordination chemistry, $o$-vanillin [5] and its substituted derivatives have been rarely employed as precursors for nitronylnitroxide ligands. To the best of our knowledge, there is only one report on the synthesis of the nitronyl-nitroxide obtained from $o$-vanillin [6], but this radical has never been employed as a ligand. This might be related to the poor yield of the synthesis of the radical derived from $o$-vanillin. A more convenient method consists in employment of derivatives that contain a substituent in para position with respect to the phenolic group, preventing the formation of by-products during the oxidation step with sodium periodate. The nitro derivative can be easily synthesized from $o$-vanillin and nitric acid and is subsequently transformed into the desired radical, HL (Scheme 1) [7]. In this paper we report on the synthesis, crystal structure 
and physical properties of two new mononuclear compounds, which contains $\mathrm{L}^{-}$as a ligand: $\left(\mathrm{Et}_{3} \mathrm{NH}\right)\left[\mathrm{M}(\mathrm{hfac})_{2} \mathrm{~L}\right](\mathrm{M}=\mathrm{Ni}, \mathrm{Zn})$.

\section{EXPERIMENTAL PART}

\subsection{General procedures}

Synthesis of 2,3-dimethyl-2,3-dinitrobutane and 2-hydroxy-3-methoxy-5-nitrobenzaldehyde were performed according to the reported procedures [8,9]. All other reagents and solvents were commercially purchased and used without any further purification, if not stated otherwise. IR spectra were recorded on a FTIR Bruker Tensor V-37 spectrophotometer ( $\mathrm{KBr}$ pellets) in the range of $4000-400 \mathrm{~cm}^{-1}$. UV-Vis diffuse reflectance spectra were recorded on a JASCO V-670 spectrophotometer on undiluted samples in the range $200-1800 \mathrm{~nm}$. Elemental analyses $(\mathrm{C}, \mathrm{H}, \mathrm{N})$ were performed on a EuroEA Elemental Analyzer. All Nuclear Magnetic Resonance $\left({ }^{1} \mathrm{H}\right.$ and ${ }^{13} \mathrm{C}$ NMR) measurements were recorded on a Bruker $500 \mathrm{MHz}$ spectrometer, at $25^{\circ} \mathrm{C}$ in $\mathrm{CDCl}_{3}$. The $\mathrm{X}$-ray powder diffraction measurements were carried out on a Proto AXRD Benchtop using $\mathrm{Cu}-\mathrm{K} \alpha$ radiation with a wavelength of $1.54059 \AA$ in the range $5-35^{\circ}(2 \theta)$. The metal ratio in the compound $\left[\mathrm{Ni}_{0.2} \mathrm{Zn}_{0.8}\right]$ was determined using the element energy dispersive spectroscopy (EDS) system (Smart Insight AMETEK), coupled with a Nova NanoSEM 630 Scanning Electron Microscope (FEI Company, Hillsboro, OR, USA). The EDAX spectrum was acquired at an acceleration voltage of $18 \mathrm{kV}$, with a working distance of $5 \mathrm{~mm}$ and 30000x magnification.

The EPR spectra were recorded with a JEOL FA 100 spectrometer equipped with a VT controller using the following setting: microwave power $1 \mathrm{~mW}$, frequency $100 \mathrm{kHz}$, sweep field $2000 \mathrm{G}$, center field $3221.8 \mathrm{G}$, sweep time $1800 \mathrm{~s}$, modulation width $2 \mathrm{G}$.

The magnetic field calibration was performed with a DPPH (diphenylpicrylhydrazyl) standard marker, exhibiting a narrow EPR line at $\mathrm{g}=2.0036$. The EPR spectra of $\mathrm{Zn}$ and $\mathrm{Ni}$ complexes and their mixture (molar ratio $\mathrm{Ni} / \mathrm{Zn} 2: 8$ ) were recorded by filling a glass capillary that was placed in an EPR tube. For solution samples, the complexes or nitronyl-nitroxide radical were dissolved in $\mathrm{CH}_{2} \mathrm{Cl}_{2}$. The oxygen has been removed from solution by bubbling Ar gas. Frozen spectra were recorded at $120 \mathrm{~K}$. The $\mathrm{a}_{\mathrm{N}}$ values of nitronyl-nitroxide radical were obtained by simulation of experimental spectra using Winsim program.

Magnetic measurements for 1 were carried out with a Quantum Design MPMS 5S SQUID magnetometer in the temperature range $2-300 \mathrm{~K}$. The crystalline powder of the complex was mixed with grease in a gelatin capsule. The temperature dependence of the magnetization was 
collected in an applied field of $1 \mathrm{kOe}$ and the isothermal field dependence of the magnetizations were collected up to $5 \mathrm{~T}$. The molar susceptibility $\left(\chi_{\mathrm{M}}\right)$ was corrected for sample holder, grease and for the diamagnetic contribution of all the atoms by using Pascal's tables. Possible slow relaxation of the magnetization was examined by AC susceptibility collected in zero field and with applied fields.

Table 1. Crystallographic data, details of data collection and structure refinement parameters for compounds $\mathbf{1}$ and $\mathbf{2}$.

\begin{tabular}{lcc}
\hline Complex & $\mathbf{1}$ & $\mathbf{2}$ \\
\hline Empirical formula & $\mathrm{C}_{30} \mathrm{H}_{35} \mathrm{~N}_{4} \mathrm{NiO}_{10} \mathrm{~F}_{12}$ & $\mathrm{C}_{30} \mathrm{H}_{35} \mathrm{~N}_{4} \mathrm{ZnO}_{10} \mathrm{~F}_{12}$ \\
Formula weight & 898.33 & 904.99 \\
Temperature $(\mathrm{K})$ & 293.15 & 293.15 \\
Crystal system & Monoclinic & Monoclinic \\
Space group & $P{ }_{1} / \mathrm{c}$ & $P{ }_{1} / \mathrm{c}$ \\
$\mathrm{a}(\AA)$ & $20.2955(15)$ & $20.4327(7)$ \\
$\mathrm{b}(\AA)$ & $9.6043(6)$ & $9.5457(2)$ \\
$\mathrm{c}(\AA)$ & $21.5013(15)$ & $21.5624(7)$ \\
$\alpha\left(^{\circ}\right)$ & 90 & 90 \\
$\beta\left(^{\circ}\right)$ & $110.349(5)$ & $111.461(4)$ \\
$\gamma\left({ }^{\circ}\right)$ & 90 & 90 \\
Volume $\left(\AA^{3}\right)$ & $3929.6(5)$ & $3914.0(2)$ \\
$Z$ & 4 & 4 \\
$\mathrm{D}_{\mathrm{c}}\left(\mathrm{g} /\right.$ cm $\left.^{3}\right)$ & 1.518 & 1.536 \\
Absorption coefficient $\left(\mathrm{mm}^{-1}\right)$ & 0.607 & 0.741 \\
$F(000)$ & 1836.04 & 1844.0 \\
$\theta$ range for data collection $\left({ }^{\circ}\right)$ & 1.93 to 24.999 & 2.03 to 30.783 \\
Index ranges & $-24 \leq h \leq 24,-11 \leq k \leq 11$, & $-25 \leq h \leq 26,-10 \leq k \leq 13$, \\
& $-25 \leq l \leq 25$ & $-26 \leq l \leq 27$ \\
Reflections collected & 40888 & 39190 \\
Independent reflections $\left[R_{\text {int }}\right]$ & $6936\left[R_{\text {int }}=0.1320\right]$ & $9656\left[R_{\text {int }}=0.0337\right]$ \\
Completeness to $\theta$ full $(\%)$ & 100.0 & 100.0 \\
Data/restraints/parameters & $6936 / 18 / 642$ & $9656 / 25 / 654$ \\
Goodness of fit on $F^{2}$ & 1.039 & 1.015 \\
$R_{l}, w R_{2}[I>2 \sigma I]$ & $0.0596,0.1108$ & $0.0378,0.0984$ \\
$R_{l}, w R_{2}($ all data) & $0.1414,0.1476$ & $0.0680,0.1111$ \\
Largest diff. peak/hole $\left(\AA^{3}\right)$ & $0.23 /-0.34$ & $0.28 /-0.24$ \\
\hline
\end{tabular}

\subsection{X-Ray data collection and crystal structure refinement}

Crystallographic data were collected on a STOE IPDS II diffractometer for $\mathbf{1}$ and on a Rigaku XtaLAB Synergy, single source at offset/far, HyPix diffractometer for 2, using a graphitemonochromated Mo $\mathrm{K}_{\alpha}$ radiation source $(\lambda=0.71073 \AA)$. The structures were solved by direct methods and refined by full-matrix least squares techniques based on $F^{2}$. The non-H atoms were refined with anisotropic displacement parameters. Hydrogen atoms were placed in fixed, idealized positions and refined as rigidly bonded to the corresponding atoms. Calculations were performed using SHELXT and SHELXL-2015 crystallographic software 
packages [10] A summary of the crystallographic data and the structure refinement is given in Tables 1 and S1 CCDC reference numbers: 2032386 (1); 2032384 (2); $2032385\left(\mathrm{Ni}_{0.2} \mathrm{Zn}_{0.8}\right)$.

\subsection{Synthesis of 2,3-bis(hydroxylamino)-2,3-dimethylbutan}

The synthesis of this ligand was adapted from reported procedure [11]. A solution of $\mathrm{HgCl}_{2}$ $(1.028 \mathrm{~g}, 3.78 \mathrm{mmol})$ in $50 \mathrm{~mL}$ of water was added over strips of aluminum foil $(1.534 \mathrm{~g}$, $57.82 \mathrm{mmol})$. The mixture was stirred for 2 minutes after which the liquid was removed with a pipet. The amalgamated aluminum was cooled keeping it in a glassware immersed in an ice bath and then a solution of 2,3-dimethyl-2,3-dinitrobutane ( $2 \mathrm{~g}, 11.36 \mathrm{mmol})$ in $60 \mathrm{~mL}$ of tetrahydrofuran (THF) and $6 \mathrm{~mL}$ of $\mathrm{H}_{2} \mathrm{O}$ were added sequentially. The reaction is left to evolve $1 \mathrm{~h}$ under strong stirring at low temperature followed by filtration on a pad of celite which was washed with another $60 \mathrm{~mL}$ of THF. The solvents from the filtered solution were removed under vacuum, to obtain a white precipitate. The precipitate was dissolved in $25 \mathrm{~mL}$ of $\mathrm{CHCl}_{3}$ over which $25 \mathrm{~mL}$ of diethyl ether were added. The solution was left overnight in the freezer to form the product as a white crystalline powder, $0.555 \mathrm{~g}$, yield $33 \%$. The product was stored dried in a fridge. Anal. Calcd. for $\mathrm{C}_{6} \mathrm{H}_{16} \mathrm{~N}_{2} \mathrm{O}_{2}(\%)$ : C, 48.63; H, 10.88; N, 18.90. Found: C, 48.68; H, 10.90; N, 18.96. Selected IR peaks $\left(\mathrm{cm}^{-1}\right): 3368$ (s), 3287 (s), 3252 (vs), 2988 (vs), 2943 (s), 1479 (m), 1452 (m), 1425 (m), 1404 (s), 1387 (s), 1375 (s), 1358 (m), 1261 (m), 1177 (m), 1146 (s), 1080 (m), 1036 (m), 989 (w), 951 (m), 932 (w), 905 (s), 853 (w), 791 (w), 690 (m), 609 (w), 494 (w), 441(w). ${ }^{1} \mathrm{H}-\mathrm{RMN}\left(500.13 \mathrm{MHz}, \mathrm{CDCl}_{3}, \delta\right.$ ppm): 1.19 (s, $\left.12 \mathrm{H}, \mathrm{CH}_{3^{-}}\right) ;{ }^{13} \mathrm{C}-\mathrm{RMN}\left(125.77 \mathrm{MHz}, \mathrm{CDCl}_{3}, \delta \mathrm{ppm}\right): 62.97\left(\mathrm{CH}_{3}-\mathrm{C}_{-} \mathrm{CH}_{3}\right)$, $20.81\left(\mathrm{CH}_{3^{-}}\right)$.

\subsection{Synthesis of 2-(2-Hydroxy-3-methoxy-5-nitrophenyl)-4,4,5,5-tetramethyl-4,5-dihydro- 1H-imidazol-3-oxide-1-oxyl (HL)}

The synthesis of this ligand was devised and adapted from reported procedures [2,7]. To a solution of 2,3-bis(hydroxylamino)-2,3-dimethylbutan (1.523 g, $10.288 \mathrm{mmol})$ in $50 \mathrm{~mL}$ of $\mathrm{MeOH}$, another solution of 2-hydroxy-3-methoxy-5-nitrobenzaldehyde (1.843 g, 9.353 $\mathrm{mmol}$ ) in $75 \mathrm{~mL}$ of $\mathrm{MeOH}$ was added. The mixture was refluxed for $4 \mathrm{~h}$ followed by the evaporation of the solvent under vacuum. Over the yellow intermediate, $100 \mathrm{~mL}$ of $\mathrm{CHCl}_{3}$ was added and the solution was ice cooled then, a solution of $\mathrm{NaIO}_{4}(2.002 \mathrm{~g}, 9.353 \mathrm{mmol})$ in $100 \mathrm{~mL}$ of water was added. The obtained biphasic system was placed under strong stirring and the reaction left to evolve at $0{ }^{\circ} \mathrm{C}$ for $15 \mathrm{~min}$ and then at $25{ }^{\circ} \mathrm{C}$ for $45 \mathrm{~min}$. The organic phase was isolated using a separatory funnel and dried with $\mathrm{MgSO}_{4}$. The solvent was 
evaporated under vacuum to obtain the crude blue product which was recrystallized four times from a mixture of $\mathrm{CH}_{2} \mathrm{Cl}_{2}$ : diethyl ether, $1: 1$ volumetric ratio, to obtain the pure blue product, $1.391 \mathrm{~g}$, yield 46\%. Anal. Calcd. for $\mathrm{C}_{14} \mathrm{H}_{18} \mathrm{~N}_{3} \mathrm{O}_{6}(\%)$ : C, 51.85; H, 5.59; N, 12.97 . Found: C, 52.27; H, 5.41; N, 12.75. Selected IR peaks $\left(\mathrm{cm}^{-1}\right)$ : $1581(\mathrm{w}), 1530(\mathrm{~m}), 1462(\mathrm{~m})$, 1429 (m), 1394 (m), 1373 (w), 1350 (vs), 1258 (m), 1201 (w), 1163 (m), 1138 (w), 1105 (w), 1069 (w), 923 (w), 885 (w), 739 (m), 457 (m). UV-Vis (nm): 362, 571.

\subsection{Synthesis of $\left(\mathrm{Et}_{3} \mathrm{NH}\right)\left[\mathrm{NiL}(\mathrm{hfac})_{2}\right], 1$}

$\mathrm{Ni}(\mathrm{hfac})_{2} \cdot 2 \mathrm{H}_{2} \mathrm{O}(0.060 \mathrm{~g}, 0.1852 \mathrm{mmol})$ was dissolved in $15 \mathrm{~mL}$ of heptane and refluxed for $30 \mathrm{~min}$. Then, after cooling down the solution, another $15 \mathrm{~mL}$ of $\mathrm{CH}_{2} \mathrm{Cl}_{2}$ solution containing HL (0.094 g, $0.1852 \mathrm{mmol})$ and 1 drop of triethylamine was added. The solution is refluxed another $30 \mathrm{~min}$, cooled down and filtered. After allowing the solvent to slowly evaporate for three days, needle shaped violet crystals of the product were obtained, $0.125 \mathrm{~g}$, yield $75 \%$. Anal. Calcd. for $\mathrm{C}_{30} \mathrm{H}_{35} \mathrm{~F}_{12} \mathrm{~N}_{4} \mathrm{O}_{10} \mathrm{Ni}(\%)$ : C, 40.11; H, 3.93; N, 6.24; Found: C, 39.61; H, 4.13; N, 5.87. Selected IR peaks ( $\left.\mathrm{cm}^{-1}\right): 1657$ (s), 1645 (s), $1600(\mathrm{w}), 1555$ (m), 1524 (s), 1502 (s), 1396 (w), 1364 (m), 1310 (s), 1256 (vs), 1234 (m), 1204 (vs) 1148 (vs), 1097 (m), 1070 (w), 870 (w), 793 (m), 673 (m), 586 (w). UV-Vis (nm): 413, 571, 751, 1142.

\subsection{Synthesis of $\left(\mathrm{Et}_{3} \mathrm{NH}\right)\left[\mathrm{ZnL}(\mathrm{hfac})_{2}\right], 2$}

$\mathrm{Zn}(\mathrm{hfac})_{2} \cdot 2 \mathrm{H}_{2} \mathrm{O}(0.047 \mathrm{~g}, 0.0926 \mathrm{mmol})$ was dissolved in $7 \mathrm{~mL}$ of heptane and refluxed for $30 \mathrm{~min}$. Then, after cooling down the solution, another $7 \mathrm{~mL}$ of $\mathrm{CH}_{2} \mathrm{Cl}_{2}$ solution containing HL (0.030 g, $0.0926 \mathrm{mmol})$ and 1 drop of triethylamine was added. The solution is refluxed another $30 \mathrm{~min}$, cooled down and filtered. After allowing the solvent to slowly evaporate for three days, needle shaped violet crystals of the product were obtained, $0.046 \mathrm{~g}$, yield $55 \%$. Anal. Calcd. for $\mathrm{C}_{30} \mathrm{H}_{35} \mathrm{~F}_{12} \mathrm{~N}_{4} \mathrm{O}_{10} \mathrm{Zn}(\%)$ : C, 39.82; H, 3.90; N, 6.19; Found: C, 40.33; H, 3.80; N, 6.06. Selected IR peaks $\left(\mathrm{cm}^{-1}\right)$ : $1663(\mathrm{~m}), 1649$ (s), $1601(\mathrm{~m}), 1557(\mathrm{~m}), 1528(\mathrm{~s})$, 1504 (s), 1399 (w), 1366 (m), 1331 (m), 1310 (s), 1286 (m), 1256 (vs), 1234 (m), 1204 (s), 1144 (vs), 1096 (m), 1071 (w), 869 (w), 795 (m), 765 (w), 746 (w), 669 (m), 583 (w). UVVis (nm): 424, 584.

The molecular alloy, $\left[\mathrm{Ni}_{0.2} \mathrm{Zn}_{0.8}\left(\mathrm{~L}(\mathrm{hfac})_{2}\right]\right.$, has been obtained by reacting the zinc and nickel salts in 1:4 molar ratio, in the same experimental conditions described above for compounds 1 and 2. The powder X-Ray diffractogram is similar to those recorded for compounds 1 and 2 (Figure S3) The Ni:Zn molar ratio in the resulting alloy was confirmed by EDX measurements. 


\subsection{Computational details}

The exchange coupling interaction was calculated by the DFT method using the Gaussian 09 program [12], considering two spin states, namely a low $\left(S=1 / 2\right.$ resulting from $S_{\mathrm{Ni}}=1$ and $S_{\text {Rad }}=-1 / 2$ spin states $)$ and a high spin HS $\left(S=3 / 2\right.$ resulting from $S_{\mathrm{Ni}}=1$ and $S_{\mathrm{Rad}}=1 / 2$ spin states) one. The calculations were performed on the crystal geometry without further optimization. The energy of the low spin state, hereafter labeled as the Broken Symmetry (BS) state, was calculated by the fragment procedure as implemented in the Gaussian09 program and further checked for its stability. The calculations were performed using the basis set, TZVP [13], and three functionals, uB3LYP [14], uB3PW91 [15], and uM06 [16]. The EPR spectra of the two $\mathrm{Ni}$ and $\mathrm{Zn}$ complexes were firstly calculated using the same theoretical model and the crystal geometry, but considering literature data [17], we have also used a new basis set recommended for EPR, TZVP/ EPR-III, and a very simple one, 6-31g*. Taking into account the results obtained by these models, the DCM solution spectra were calculated using only the TZVP and the 6-31 $\mathrm{g} *$ basis sets after the geometry optimization in the solvent.

\section{RESULTS AND DISCUSSION}

\subsection{Description of the crystal structures}

The new compounds, $\left(\mathrm{Et}_{3} \mathrm{NH}\right)\left[\mathrm{M}(\mathrm{hfac})_{2} \mathrm{~L}\right](\mathrm{M}=\mathrm{Ni}$ 1, Zn 2), have been synthesized by reacting the metal precursors, $\left[\mathrm{M}(\mathrm{hfac})_{2}\left(\mathrm{H}_{2} \mathrm{O}\right)_{2}\right]$ with the paramagnetic proligand, $\mathrm{HL}$, in the presence of triethylamine, which was added for the deprotonation of the phenolic group. The PXRD patterns for 1 and $\mathbf{2}$ confirm the purity of the crystalline phases (Figures S1 and S2). Since the two compounds are isostructural, only the crystal structure of $\mathbf{1}$ will be described in detail.

Its crystal structure consists of anionic complexes, $\left[\mathrm{Ni}(\mathrm{hfac})_{2} \mathrm{~L}\right]^{-}$(Figure 1) and organic cations, $\mathrm{Et}_{3} \mathrm{NH}^{+}$. The nickel ion shows an octahedral geometry, being coordinated by four oxygen atoms arising from the hfac ${ }^{-}$ligands and two others from $\mathrm{L}^{-}$(one phenoxido and one aminoxyl oxygen). The $\mathrm{Ni}-\mathrm{O}$ oxygen distances vary between 2.008(4) and 2.072(4) $\AA$. The $\mathrm{N}-\mathrm{O}$ bond within the aminoxyl group coordinated to $\mathrm{Ni}^{\mathrm{II}}(1.305(5) \AA)$ is longer than the one within the uncoordinated NO group (1.266(5) $\AA$ ). The complex species are chiral and both enantiomers co-crystallize within the same crystal (Figure 2). The crystal structure of the complex anion in $\mathbf{2}$ is illustrated in Figure S4. Selected bond distances and angles for compounds $\mathbf{1}$ and $\mathbf{2}$ are collected in Table 2. 


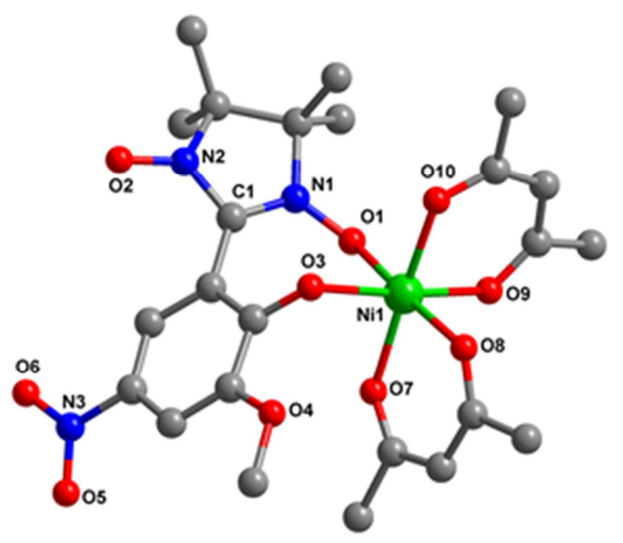

Figure 1. Molecular structure of the complex anion 1, along with the atom numbering scheme. Hydrogen and fluorine atoms have been omitted for clarity.

The diffuse reflectance spectra of the ligand and the two complexes are displayed in Figure 3. Compound 1 shows, apart from the bands arising from the organic ligands, two other bands which are due to the $d$ - $d$ transitions: ${ }^{3} \mathrm{~A}_{2} \rightarrow{ }^{3} \mathrm{~T}_{2}(1122 \mathrm{~nm})$ and ${ }^{3} \mathrm{~A}_{2} \rightarrow{ }^{3} \mathrm{~T}_{1}(751 \mathrm{~nm})$, assuming the $O_{h}$ point group.

One single crystal from the $\left[\mathrm{Ni}_{0.2} \mathrm{Zn}_{0.8}\right]$ sample was measured, and the structure was refined with occupation factors 0.2 for $\mathrm{Ni}$ and 0.8 for $\mathrm{Zn}$ (Table S1), in agreement with the EDX data. The powder X-Ray diffractogram for the alloy (Figure S3) is identical with those of $\mathbf{1}$ and 2.

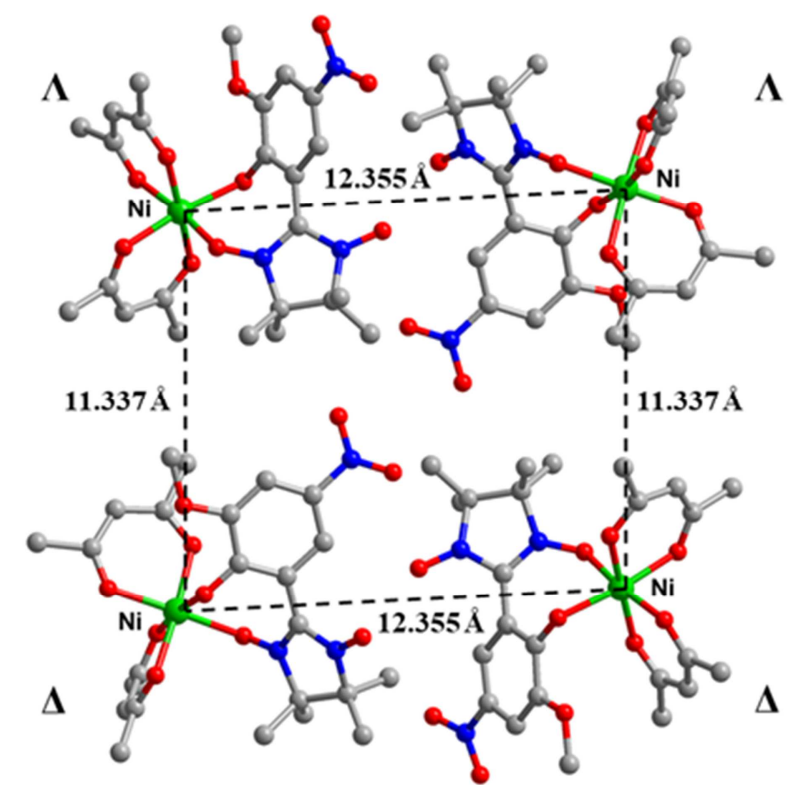

Figure 2. The packing diagram of $\mathbf{1}$ showing the closest distances between nickel metal ions and delta $(\Delta)$ or lambda $(\Lambda)$ configurations of the metal centers. 
Table 2. Selected bond distances $(\AA)$ and angles $\left(^{\circ}\right)$ for compounds $\mathbf{1}$ and $\mathbf{2}$.

\begin{tabular}{cccc}
\hline & $\mathbf{5}$ & \multicolumn{2}{c}{} \\
\hline Distances & & Distances \\
Ni1-O1 & $2.072(4)$ & Zn1-O1 & $2.204(2)$ \\
Ni1-O3 & $2.035(3)$ & Zn1-O3 & $2.035(1)$ \\
Ni1-O7 & $2.046(4)$ & Zn1-O7 & $2.095(2)$ \\
Ni1-O8 & $2.029(4)$ & Zn1-O8 & $2.089(2)$ \\
Ni1-O9 & $2.008(4)$ & Zn1-O9 & $2.051(2)$ \\
Ni1-O10 & $2.026(4)$ & Zn1-O10 & $2.090(2)$ \\
Angles & & Angles & \\
O1-Ni1-O3 & $89.53(13)$ & O1-Zn1-O3 & $85.93(5)$ \\
O1-Ni1-O7 & $89.67(14)$ & O1-Zn1-O7 & $90.65(5)$ \\
O1-Ni1-O8 & $173.15(16)$ & O1-Zn1-O8 & $172.31(6)$ \\
O1-Ni1-O9 & $82.83(15)$ & O1-Zn1-O9 & $79.49(6)$ \\
O1-Ni1-O10 & $94.70(15)$ & O1-Zn1-O10 & $95.85(6)$ \\
O3-Ni1-O7 & $91.75(14)$ & O3-Zn1-O7 & $93.83(6)$ \\
O3-Ni1-O8 & $97.21(15)$ & O3-Zn1-O8 & $101.23(6)$ \\
O3-Ni1-O9 & $172.16(15)$ & O3-Zn1-O9 & $164.47(6)$ \\
O3-Ni1-O10 & $87.92(15)$ & O3-Zn1-O10 & $87.86(6)$ \\
O7-Ni1-O8 & $88.88(15)$ & O7-Zn1-O8 & $86.10(6)$ \\
O7-Ni1-O9 & $90.00(15)$ & O7-Zn1-O9 & $91.67(6)$ \\
O7-Ni1-O10 & $175.62(15)$ & O7-Zn1-O10 & $173.39(6)$ \\
O8-Ni1-O9 & $90.47(16)$ & O8-Zn1-O9 & $93.62(7)$ \\
O8-Ni1-O10 & $86.82(15)$ & O8-Zn1-O10 & $87.30(6)$ \\
O9-Ni1-O10 & $90.91(15)$ & O9-Zn1-O10 & $88.34(6)$ \\
\hline
\end{tabular}

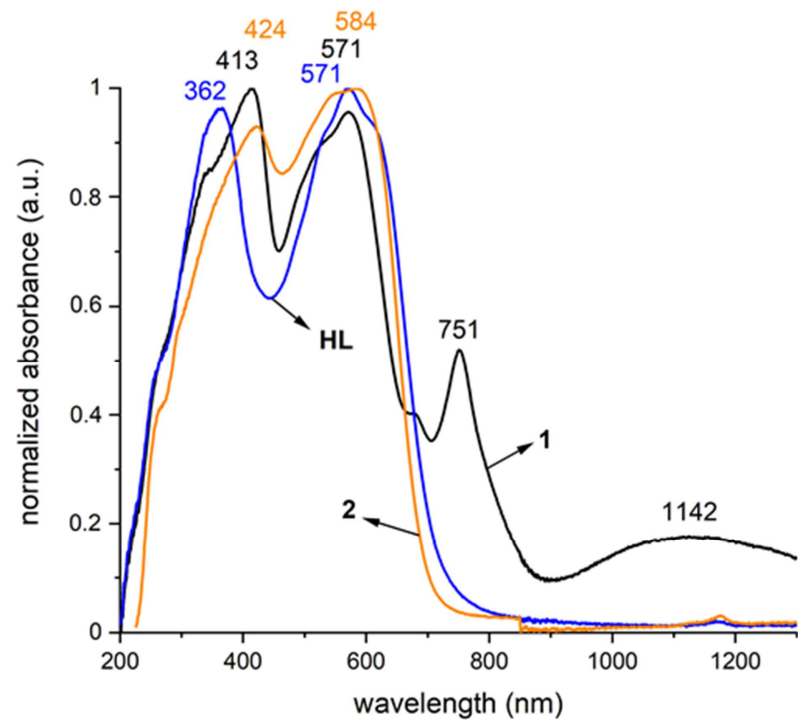

Figure 3. Diffuse reflectance spectra for HL and complexes 1 and 2.

\subsection{Magnetic properties of $\left(\mathrm{Et}_{3} \mathrm{NH}\right)\left[\mathrm{NiL}(\mathrm{hfac})_{2}\right]$}

The temperature dependence of the molar magnetic susceptibility, $\chi_{\mathrm{M}}$, for $\mathbf{1}$ has been investigated in the temperature range $2-300 \mathrm{~K}$, and the field dependence of the magnetization was recorded at $2 \mathrm{~K}$. The $\chi_{\mathrm{M}} T$ vs. $T$ and $M$ vs. $H$ plots are presented in Figure 4. The value of $\chi_{\mathrm{M}} T$ found at $300 \mathrm{~K}$ is $0.70 \mathrm{~cm}^{3} \mathrm{~mol}^{-1} \mathrm{~K}$, much smaller than the expected 1.375 
$\mathrm{cm}^{3} \mathrm{~mol}^{-1} \mathrm{~K}$ for the uncoupled $S=1\left(\mathrm{Ni}^{\mathrm{II}}\right)$ and $S=1 / 2(\mathrm{Rad})$. Moreover, reducing the temperature, $\chi_{\mathrm{M}} T$ decreases to $0.475 \mathrm{~cm}^{3} \mathrm{~mol}^{-1} \mathrm{~K}$ at $120 \mathrm{~K}$ and below remains constant down to $2 \mathrm{~K}$. Such a behavior is indicative for a strong antiferromagnetic Radical-Ni(II) interaction. The plateau reached below $150 \mathrm{~K}$ is the signature of a spin $S=1 / 2$, resulting from the antiferromagnetic interaction between the spins $S=1 / 2$ and 1 . The resulting $S=1 / 2$ ground state is further confirmed by the field dependence of the magnetization recorded at $2 \mathrm{~K}$ that tends to $1 \mu_{\mathrm{B}}$ at $5 \mathrm{~T}$.

These magnetic data have been analysed using the HDvV Hamiltonain: $\boldsymbol{H}=-J \boldsymbol{S}_{\mathrm{Ni}} \boldsymbol{S}_{\text {Rad.. }}$ In order to avoid over-parameterization, only a mean $g$ parameter was considered (the local $g$ parameters were accurately determined by EPR spectroscopy, vide infra). The best fit yielded $J=-351 \pm 1 \mathrm{~cm}^{-1}$ and $g=2.185 \pm 0.001$.

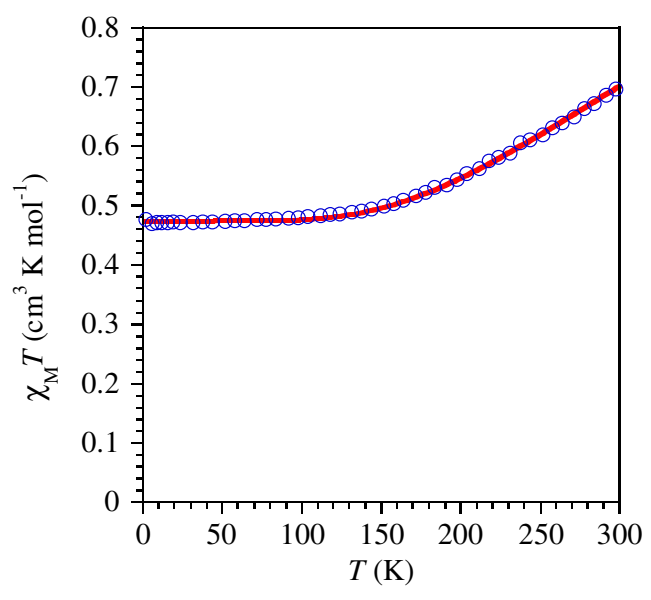

(a)

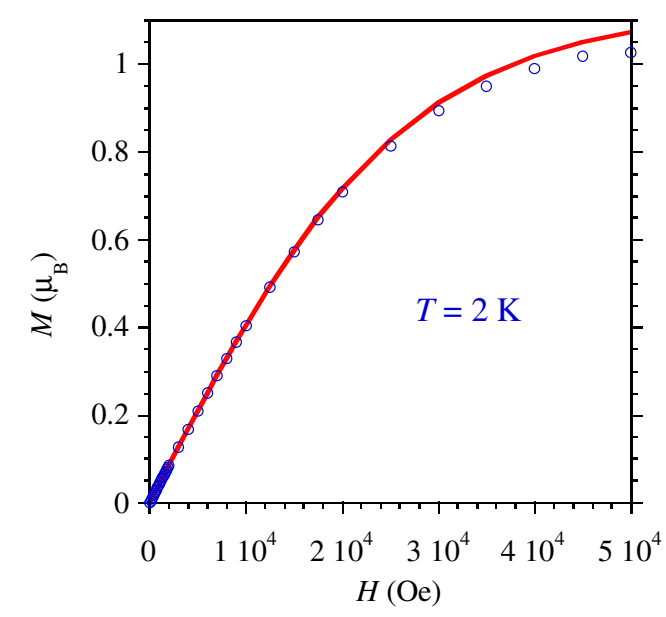

(b)

Figure 4. Magnetic behavior for 1: experimental (O) and calculated (-) (a) temperature dependence of the $\chi_{\mathrm{M}} T$ and (b) magnetization vs. field

The nature of the exchange interactions (antiferro- and ferromagnetic) between nickel(II) and the aminoxyl group was subject of several magneto-structural correlations studies [18]. We recall here the most important conclusions, resulting from both experimental and theoretical investigations: (i) the coplanarity between the radical ring and the equatorial plane of the octahedral $\mathrm{Ni}^{\mathrm{II}}$ ion favors a ferromagnetic coupling (the $d_{x 2-y 2}$ and $\pi^{*}$ radical orbital are orthogonal, while the overlap with the $d_{z 2}$ orbital is symmetry forbidden); (ii) the Ni-O-N-C dihedral angle as well as the Ni-O-N angle play a crucial on the overlap of the magnetic orbitals; (iii) large overlaps between the magnetic orbitals, and, consequently, strong antiferromagnetic interactions are favored by M-O-N-C dihedral angles close to $90^{\circ}$ and by Ni-O-N angles close to $120^{\circ}$. These geometrical parameters for complex 1 (Ni1-O1-N1 = 
126.1 $(3)^{\circ}$, Ni1-O1-N1-C1 $\left.=58.6(6)^{\circ}\right)$ suggest that the coupling between the nickel(II) ion and the radical must be antiferromagnetic and quite strong, in line with the experimental value.

DFT calculations undertaken for $\mathbf{1}$ confirm the strong antiferromagnetic interaction between the paramagnetic centers, the ground state of the complex being the low spin state, i.e. the broken symmetry one. Starting from the spin Hamiltonian previously mentioned, $\boldsymbol{H}=-$ $J \boldsymbol{S}_{\mathrm{Ni}} \boldsymbol{S}_{\mathrm{Rad}}$, the $J$ value was obtained using the equation (1) [19]:

$J=\left(E_{\mathrm{BS}}-E_{\mathrm{HS}}\right) /\left(2 \boldsymbol{S}_{\mathrm{Ni}} \mathbf{S}_{\mathrm{Rad}}+\boldsymbol{S}_{\mathrm{Rad}}\right)$

The results presented in Table 3 are in agreement with the experimental value, $J=-351 \pm 1$ $\left(\mathrm{cm}^{-1}\right)$. It can also be remarked that the three functionals used lead to quite similar results. As can be seen in Figure 5a and b, in both states, BS and HS, the spin densities are localized on the nickel ion and on the NO groups of the nitronyl-nitroxide radical, explaining the EPR spectra, vide infra.

Table 3. Calculated $J$ values $\left(\mathrm{cm}^{-1}\right)$ for compound 1 .

\begin{tabular}{ll}
\hline Functional & Eq.(1) \\
\hline uB3LYP & -400.53 \\
uB3PW91 & -398.23 \\
uM06 & -408.51 \\
\hline
\end{tabular}

(a)

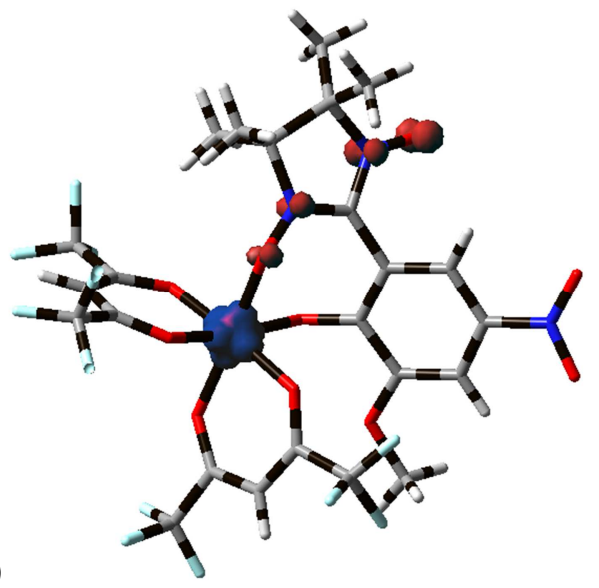

(b)

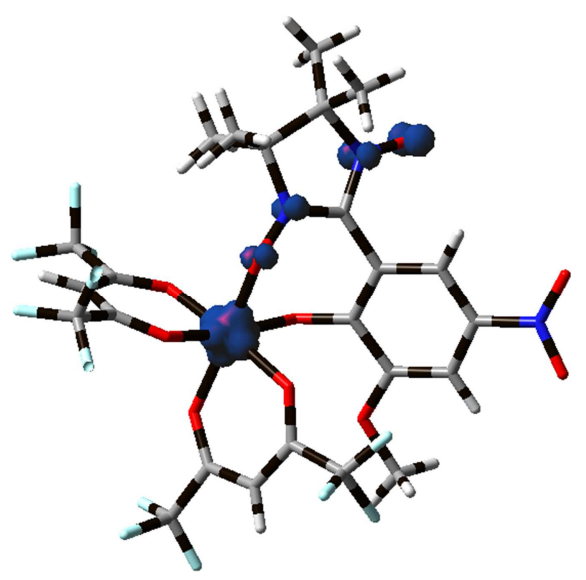

Figure 5. Spin density (0.04) isosurfaces $\left(0.04 \mathrm{e}^{-/}(\text {a.u. })^{3}\right)$ : a) BS state; b) HS state.

\subsection{EPR spectra}

The EPR spectra of the three paramagnetic compounds, the two complexes $\mathbf{1}$ and $\mathbf{2}$ and the nitronyl-nitroxide radical, were recorded both at room temperature, $293 \mathrm{~K}$ and at $120 \mathrm{~K}$. The 
spectrum of $\mathrm{HL}$ in $\mathrm{CH}_{2} \mathrm{Cl}_{2}$ at room temperature is displayed in Figure S5 and presents the known features of nitronyl-nitroxide radicals with a $g$ factor of 2.0053 and a five line spectrum due to the hyperfine splitting (hfs) of two quasi-equivalent nitrogen atoms; the values obtained by simulation are $\mathrm{a}_{\mathrm{N} 1}=7.40 \mathrm{G}, \mathrm{a}_{\mathrm{N} 2}=7.55 \mathrm{G}$. The EPR spectrum recorded at $120 \mathrm{~K}$ indicates a restricted motion (Figure $\mathrm{S} 5 \mathrm{c}$ ).

The EPR spectra of the two complexes and their mixture, recorded in $\mathrm{CH}_{2} \mathrm{Cl}_{2}$ are plotted in Figure 6. At room temperature, the spectrum of the nickel complex, 1, (Figure 6a), presents only the signal of the organic radical $(g=2.0053)$; at $120 \mathrm{~K}$, the spectrum consists of two signals, a strong one characterized by $g=2.2751$, and a very weak signal at $g=2.0051$; the first signal is characteristic to a paramagnetic species with the electron localized on the nickel center [20] while the weak one is due to the organic radical. As expected, at both temperatures the spectrum of complex 2 presents only a single signal belonging to the organic radical the spectrum is unresolved at low temperature due to a strong broadening of the lines, but the $g$ value is not influenced by temperature $(293 \mathrm{~K}, g=2.0055 ; 120 \mathrm{~K}, g=2.0051)$. The isodensity spin surface displayed in Figure S6 reflects this behavior, the spin density being localized only on the NO groups. The assignment of the EPR spectra of $\mathbf{1}$ and $\mathbf{2}$ is verified by the spectra $d$ and e in Figure 6; where it can be seen that the presence of the nickel ion determines the appearance at $120 \mathrm{~K}$ of the very weak signal at $g=2.2761$ previously assigned to the spin localization on nickel and a large signal at $\mathrm{g}=2.0056$ corresponding to complex 2 . The strong signal of nitronyl-nitroxide fragment observed at $120 \mathrm{~K}$ is due to the excess of zinc complex in solution.

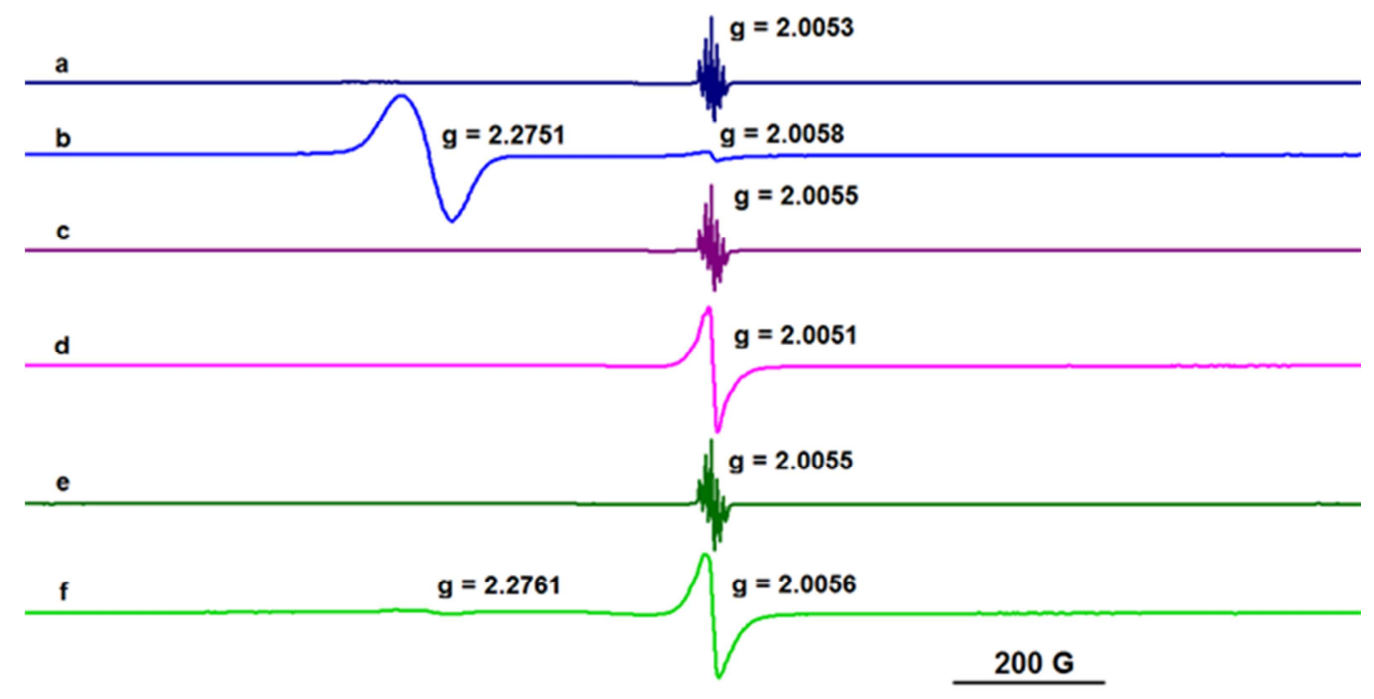

Figure 6. The EPR spectra in DCM recorded at 293 and $120 \mathrm{~K}$ : a) $\mathbf{1}$ at $293 \mathrm{~K}$; b) 1 at $120 \mathrm{~K}$; c) 2 at $293 \mathrm{~K}$; d) 2 at $120 \mathrm{~K}$; e) $\mathrm{Ni}_{0.2} \mathrm{Zn}_{0.8}$ at $293 \mathrm{~K}$; f) $\mathrm{Ni}_{02} \mathrm{Zn}_{0.8}$ at $120 \mathrm{~K}$. 
The same behavior is illustrated by the EPR spectra recorded in solid state (Figure 7), for 1, 2 and the molecular alloy $\left[\mathrm{Ni}_{0.2} \mathrm{Zn}_{0.8}\right]$. Although the isostructural zinc derivative, 2 , is not a diamagnetic host for $\mathbf{1}$, and cannot suppress all the dipolar interactions, some information can be extracted by comparing all these spectra.

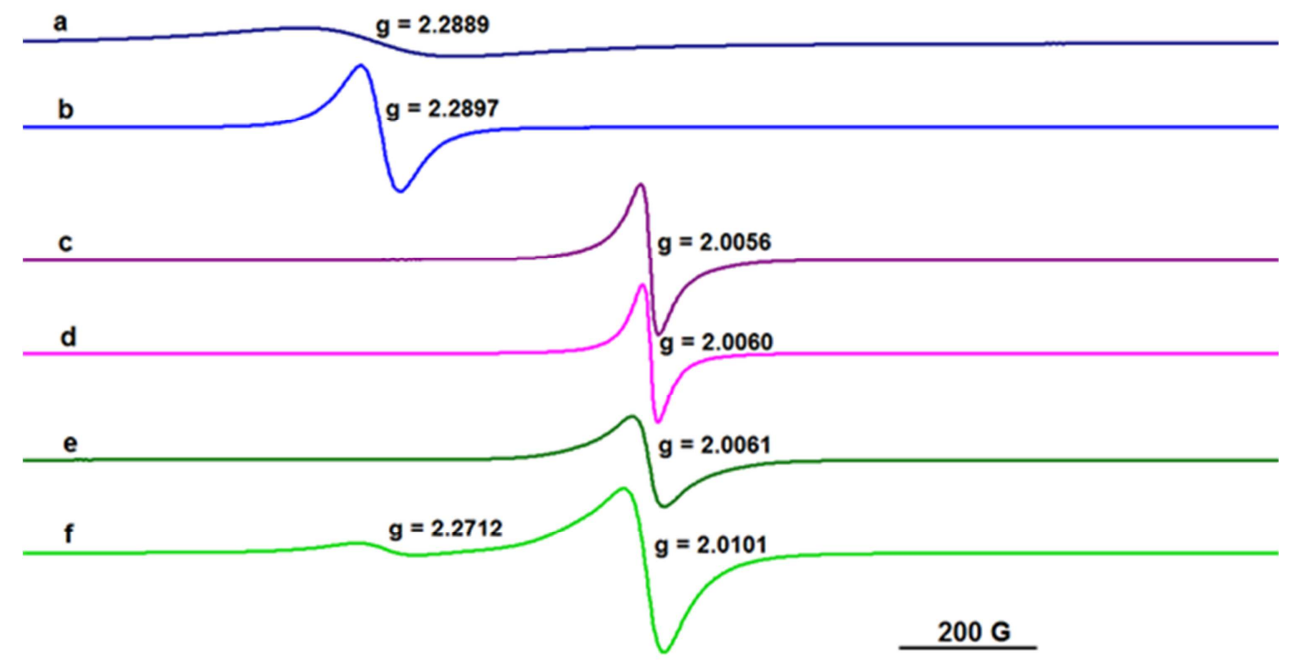

Figure 7. Solid state EPR spectra of: a) 1 at $293 \mathrm{~K}$; b) 1 at $120 \mathrm{~K}$; c) 2 at $293 \mathrm{~K}$; d) 2 at $120 \mathrm{~K}$; e) $\mathrm{Ni}_{0.2} \mathrm{Zn}_{0.8}$ at $293 \mathrm{~K}$; f) $\mathrm{Ni}_{0.2} \mathrm{Zn}_{0.8}$ at $120 \mathrm{~K}$.

At room temperature compound 1 shows only a broad and weak feature at $g=2.2889$, which is due to the $S=1 / 2$ state. As expected, this signal becomes stronger at $120 \mathrm{~K}$, where only the spin state $S=1 / 2$ is populated (Figure $7 \mathrm{~b}$ ). The spectra of the zinc derivative do not change with the temperature (Figure 7c,d). The molecular alloy of $\mathbf{1}$ and $\mathbf{2}$ shows at room temperature (Figure $7 \mathrm{e}$ ) only one signal $(g=2.0061)$ arising from complex 2 ; at $120 \mathrm{~K}$ (Figure 7f) two signals are observed: $g=2.0102$ (due to complex 2) and $g=2.2712(S=1 / 2$ ground state of $\mathbf{1}$ ).

The hyperfine splitting (hfs) constants for $\mathbf{1}$ and $\mathbf{2}$ were firstly calculated using the same model (crystal geometry, B3LYP/TZVP) as for the magnetic measurements. The results listed in Table S2 show a poor agreement with the experimental ones; it is even worse with TVZP/EPR-III. A better agreement is obtained with basis set 6-31*. Therefore, all the further calculations with $\mathrm{CH}_{2} \mathrm{Cl}_{2}$ as a solvent were performed using the TZVP and 6-31g* sets (Table 4) It can be seen that for the three paramagnetic species a good agreement is obtained with the 6-31g* basis which have also the advantage of requiring short calculation times. 
Table 4. Calculated isotropic hyperfine splitting constants $(\mathrm{G})$ for the three paramagnetic species optimized in DCM, using the UB3LYP functional and two basis sets, TZVP, and 6-31g*.

\begin{tabular}{cccccccc}
\hline & & \multicolumn{2}{c}{$\mathrm{HL}$} & \multicolumn{2}{c}{$\mathbf{1}$} & \multicolumn{2}{c}{$\mathbf{2}$} \\
\cline { 3 - 8 } & $(\mathrm{exp})$ & TZVP & $6-31 \mathrm{~g}^{*}$ & TZVP & $6-31 \mathrm{~g}^{*}$ & TZVP & $6-31 \mathrm{~g}^{*}$ \\
\hline $\mathrm{a}_{\mathrm{N} 1}$ & 7.40 & 5.33 & 7.68 & -4.98 & -7.22 & 5.12 & 7.46 \\
$\mathrm{a}_{\mathrm{N} 2}$ & 7.50 & 5.06 & 7.59 & -4.95 & -7.40 & 5.23 & 7.79 \\
\hline
\end{tabular}

In conclusion, we described dscribed two new metal-radical complxes, using for the first time, as a ligand, a nitronyl-nitroxid radical derived from $o$-vanillin. The EPR spectra of the nickel complex recorded at two different temperatures clearly show the $S=1 / 2$ ground state, in line with thee magnetic susceptibility measurements and theoretical calculations.

\section{ACKNOWLEDGMENTS}

We are thankful to Anamaria Hanganu for NMR spectra recording. Also, we are grateful to Gabriel Crăciun and Adrian Apostol for EDX measurements. 


\section{REFERENCES}

[1] D. Luneau, Eur. J. Inorg. Chem., 2020, 597 (2020); (b) S. Demir, I.-R. Jeon, J.R. Long, T.D. Harris, Coord. Chem. Rev., 289-290, 149 (2015); (c) X. Meng, W. Shi, P. Cheng, Coord. Chem. Rev., 378, 134 (2019); (d) M.T. Lemaire, Pure Appl. Chem., 76, 277 (2004); (e) C. Benelli, D. Gatteschi, Chem. Rev., 102, 2369 (2002); (f) D. Luneau, P. Rey, Coord. Chem. Rev., 249, 2591 (2005); (g) A. Caneschi, D. Gatteschi, R. Sessoli, P. Rey, Acc. Chem. Res., 22, 392 (1989).

[2] J.H. Osiecki, E.F. Ullman, J. Am. Chem. Soc., 90, 1078 (1968); (b) E.F. Ullman, L. Call, J.H. Osiecki, J. Org. Chem., 35, 3623 (1970); (c) E.F. Ullman, J.H. Osiecki, D.G.B. Boocock, R. Darcy, J. Am. Chem. Soc., 94, 7049 (1972); (d) C. Hirel, K.E. Vostrikova, J. Pécaut, V.I. Ovcharenko, P. Rey, Chem. Eur. J., 7, 2007 (2001).

[3] See, for example: (a) J. Sun, Z. Sun, L. Li, J.-P. Sutter, Inorg. Chem., 57, 7507 (2018); (b) G.P. Guedes, R.G. Zorzanelli, N.M. Comerlato, N.L. Speziali, S. SantosJr., M.G.F. Vaz, Inorg. Chem. Commun., 23, 59 (2012); (c) H. Miao, M. Li, H.-Q. Li, F.-X. Shen, Y.-Q. Zhang, X.-Y. Wang, Dalton Trans., 48, 4774 (2019); (d) Y.-F. Wang, L.-Y. Wang, L.-F. Ma, Z. Anorg. Allg. Chem., 634, 181 (2008); (e) P. Y. Chen, M. Z. Wu, T. Li, X. J. Shi, L. Tian, Z. Y. Liu, Inorg. Chem., 57, 12466 (2018); (f) P. Hu, X. Wang, Y. Ma, Q. Wang, L. Li, D. Liao, Dalton Trans., 43, 2234 (2014); (g) J. Omata, T. Ishida, D. Hashizume, F. Iwasaki, T. Nogami, Inorg. Chem., 40, 3954 (2000); (h) Z. Liu, Z. Lu, D. Zhang, Z. Jiang, L. Li, C. Liu, D. Zhu, Inorg. Chem., 43, 6620 (2004); (i) F. Furui, S. Suzuki, M. Kozaki, D. Shiomi, K. Sato, T. Takui, K. Okada, E.V. Tretyakov, S.E. Tolstikov, G.V. Romanenko, V.I. Ovcharenko, Inorg. Chem., 53, 802 (2014); (j) A. Lannes, M. Intissar, Y. Suffren, C. Reber, D. Luneau, Inorg. Chem., 53, 9548 (2014); (k) J. Guo, J. Sun, G. Sun, Z. Sun, L. Li, Eur. J. Inorg. Chem., 2018, 3241 (2018);

[4] See, for example: (a) L.B.L. Escobar, G.P.Guedes, S. Soriano, N.L. Speziali, A.K. Jordão, A.C. Cunha, V.F. Ferreira, C. Maxim, M.A. Novak, M. Andruh, M.G.F. Vaz, Inorg. Chem., 53, 7508, (2014); (b) M. Zhu, L. Li, J.-P. Sutter, Inorg. Chem. Front., 3, 994 (2016); (c) L. Xi, J. Suan, K. Wang, J. Lu, P. Jing, L. Li, Dalton Trans., 49, 1089, (2020); (d) G. Novitchi, S. Shova, Y. Lan, W. Wernsdorfer, C. Train, Inorg. Chem., 55, 12122 (2016); (e) A.A. Patrascu, S. Calancea, M. Briganti, S. Soriano, A.M. Madalan, R.A.A. Cassaro, A. Caneschi, F. Totti, M.G.F. Vaz, M. Andruh, Chem. Commun., 53, 6504 (2017); (f) A. A. Patrascu, M. Briganti, S. Soriani, S. Calancea, R. A. A. Cassaro, F. Totti, M. G. F. Vaz, M. Andruh, Inorg. Chem., 58, 13090 (2019).

[5] M. Andruh, Dalton Trans., 44, 16633 (2015).

[6] A. Vega, J. Padilla, M.A. Leyva, M. del Jesús Rosales, S. Bernès, J. Mex. Chem. Soc., 52, 54 (2008).

[7] V. Ovcharenko, O. Kuznetsova, E. Fursova, G. Letyagin, G. Romanenko, A. Bogomyakov, E. Zueva, Inorg. Chem., 56, 14567 (2017).

[8] R. Sayre, J. Am. Chem. Soc., 77, 6689 (1955).

[9] (a) D.A. Davis, A. Hamilton, J. Yang, L.D. Cremar, D.V. Gough, S.L. Potisek, M.T. Ong, P.V. Braun, T.J. Martinez, S.R. White, J.S. Moore, N.R. Sottos, Nature, 459, 68 
(2009); (b) S.S. Deshpande, M.A. Jachak, S.S. Khopkar, G.S. Shankarling, Sens. Actuators, B, 258, 648 (2018).

[10] (a) G.M. Sheldrick, Acta Cryst., A71, 3-8 (2015); (b) G.M. Sheldrick, Acta Cryst., C71, 3-8 (2015).

[11] S. Shimono, R. Tamura, N. Ikuma, T. Takimoto, N. Kawame, O. Tamada, N. Sakai, H. Matsuura, J. Yamauchi, J. Org. Chem., 69, 475 (2004).

[12] M.J. Frisch, G.W. Trucks, H.B. Schlegel, G.E. Scuseria, M.A. Robb, J.R. Cheeseman, G. Scalmani, V. Barone, B. Mennucci, G.A. Petersson, H. Nakatsuji, M. Caricato, X. Li, H.P. Hratchian, A.F. Izmaylov, J. Bloino, G. Zheng, J.L. Sonnenberg, M. Hada, M. Ehara, K. Toyota, R. Fukuda, J. Hasegawa, M. Ishida, T. Nakajima, Y. Honda, O. Kitao, H. Nakai, T. Vreven, J. A. Montgomery, J.E. Peralta, F. Ogliaro, M. Bearpark, J. J. Heyd, E. Brothers, K.N. Kudin, V.N. Staroverov, R. Kobayashi, J. Normand, K. Raghavachari, A. Rendell, J.C. Burant, S.S. Iyengar, J. Tomasi, M. Cossi, N. Rega, J. M. Millam, M. Klene, J.E. Knox, J.B. Cross, V. Bakken, C. Adamo, J. Jaramillo, R. Gomperts, R.E. Stratmann, O. Yazyev, A.J. Austin, R. Cammi, C. Pomelli, J.W. Ochterski, R.L. Martin, K. Morokuma, V.G. Zakrzewski, G.A. Voth, P. Salvador, J.J. Dannenberg, S. Dapprich, A.D. Daniels, O. Farkas, J.B. Foresman, J.V. Ortiz, J. Cioslowski, D.J. Fox, GAUSSIAN 09, Revision C.01, Gaussian, Inc., Wallingford CT (2009).

[13] F. Weigend, R. Ahlrichs, Phys. Chem. Chem. Phys., 7, 3297 (2005).

[14] A.D. Becke, J. Chem. Phys., 98, 5648 (1993).

[15] Y. Wang, J.P. Perdew, Phys. Rev., B 44, 13298 (1991).

[16] a) Y. Zhao, D.G. Truhlar, Theor. Chem. Acc. 120, 215 (2008); b) R. Valero, R. Costa, I. de P.R. Moreira, D.G. Truhlar, F. Illas, J. Chem. Phys., 128, 114103-1 (2008).

[17] (a) L. Hermosilla, J.M. Garcia de la Vega, C. Sieiro, P. Calle, J. Chem. Theory Comput., 7, 169 (2011); (b) L. Hermosilla, P. Calle, J.M.G. de la Vega, C. Sieiro, J. Phys. Chem. A, 110, 13600 (2006); (c) A. Tanaka, K. Nakashima, Magn. Reson. Chem. 49, 603 (2011); (d) C. Zhao, R. Dao, Y. Wang, J. Yao, H. Li, Chem. Phys., 517, 13 (2019); (e) L. Hermosilla, P. Calle, J.M. García de la Vega, RSC Advances 5, 62551 (2015); (f) O.I. Gromov, S.V. Kuzin, E.N. Golubeva, J. Mol. Model., 25, 93 (2019).

[18] (a) D. Luneau, F.M. Romero, R. Ziessel, Inorg. Chem., 37, 5078 (1998); (b) C. Stroh, E. Belorizky, P. Turek, H. Bolvin, R. Ziessel, Inorg. Chem., 42, 2938 (2003); (c) C. Aoki, T. Ishida, T. Nogami, Inorg. Chem., 42, 7616 (2003); (c) G. Francese, F.M. Romero, A. Neels, H. Stoeckli-Evans, S. Decurtins, Inorg. Chem., 39, 2097 (2000); (d) U. Schatzschneider, T. Weyhermüller, E. Rentschler, Eur. J. Inorg. Chem., 2001, 2569 (2001); (e) K.E. Vostrikova, E. Belorisky, J. Pécaut, P. Rey, Eur. J. Inorg. Chem., 1999, 1181 (1999); (f) T. Yoshida, T. Suzuki, K. Kanamori, S. Kaizaki, Inorg. Chem., 38, 1059, (1999).

[19] E. Ruiz, J. Cano, S. Alvarez, P. Alemany, J. Comput. Chem., 20, 1391 (1999).

[20] (a) Z.-H. Zhang, S.-Y. Wu, P. Xu, L-L Li, Braz. J. Phys., 40, 361 (2010); (b) R. Srinivasan, I. Sougandi, R. Venkatesan, P. S. Rao, Proc. Indian Acad. Sci. (Chem. Sci.), 115, 91 (2003). 


\section{Supporting information}

Synthesis, crystal structure, magnetic, spectroscopic, and theoretical investigations of two new nitronyl-nitroxide complexes

Cristian A. Spinu ${ }^{\mathrm{a}}$, Céline Pichon ${ }^{\mathrm{b}}$, Gabriela Ionita ${ }^{\mathrm{c}}$, Teodora Mocanu ${ }^{\mathrm{a}, \mathrm{d}}$, Sergiu Calancea ${ }^{\mathrm{a}, \mathrm{e}}$, Mihai Raduca $^{\mathrm{a}}$, Jean-Pascal Sutter ${ }^{\mathrm{c}}$, Mihaela Hillebrand ${ }^{\mathrm{f}}$ and Marius Andruh ${ }^{\mathrm{a}}$

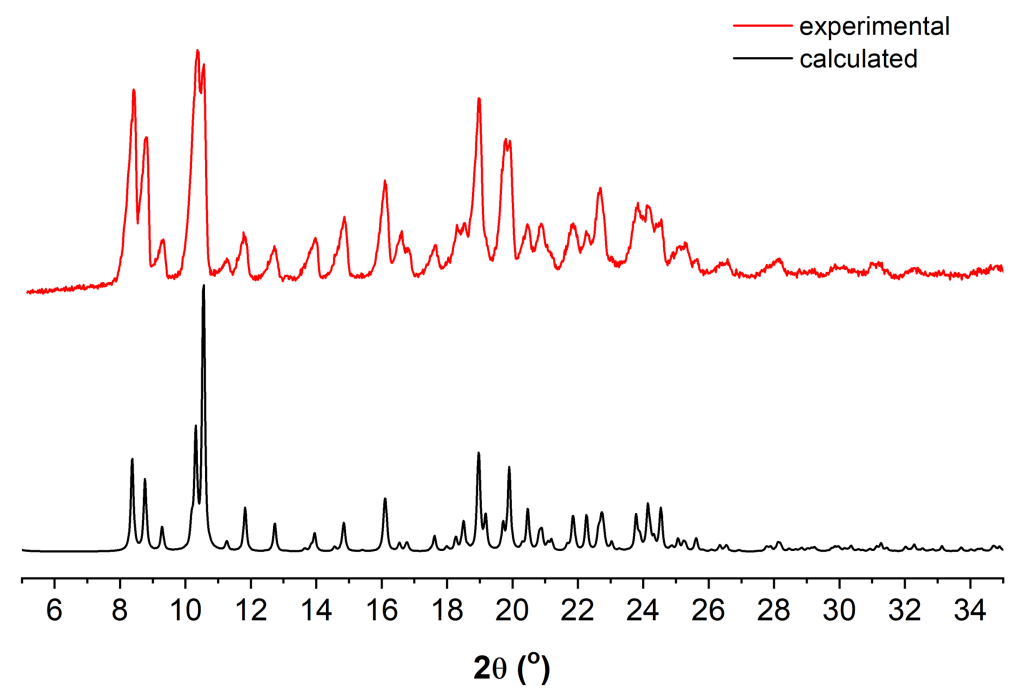

Figure S1. Measured (red) and calculated (black) powder X-ray diffraction patterns of $\mathbf{1}$. 


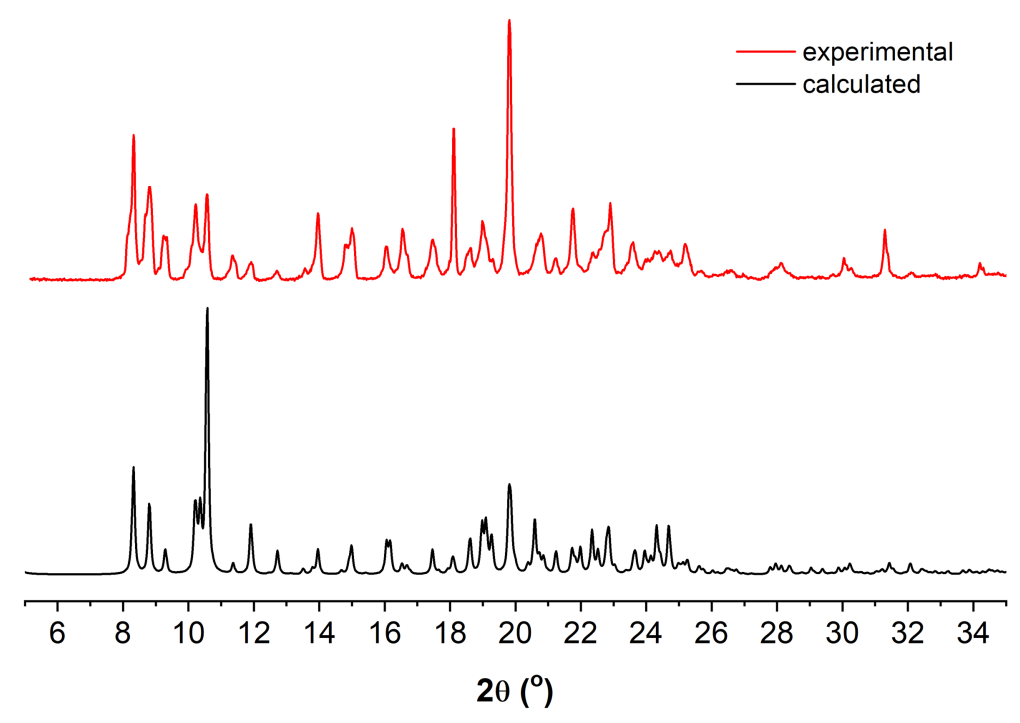

Figure S2. Measured (red) and calculated (black) powder X-ray diffraction patterns of 2.

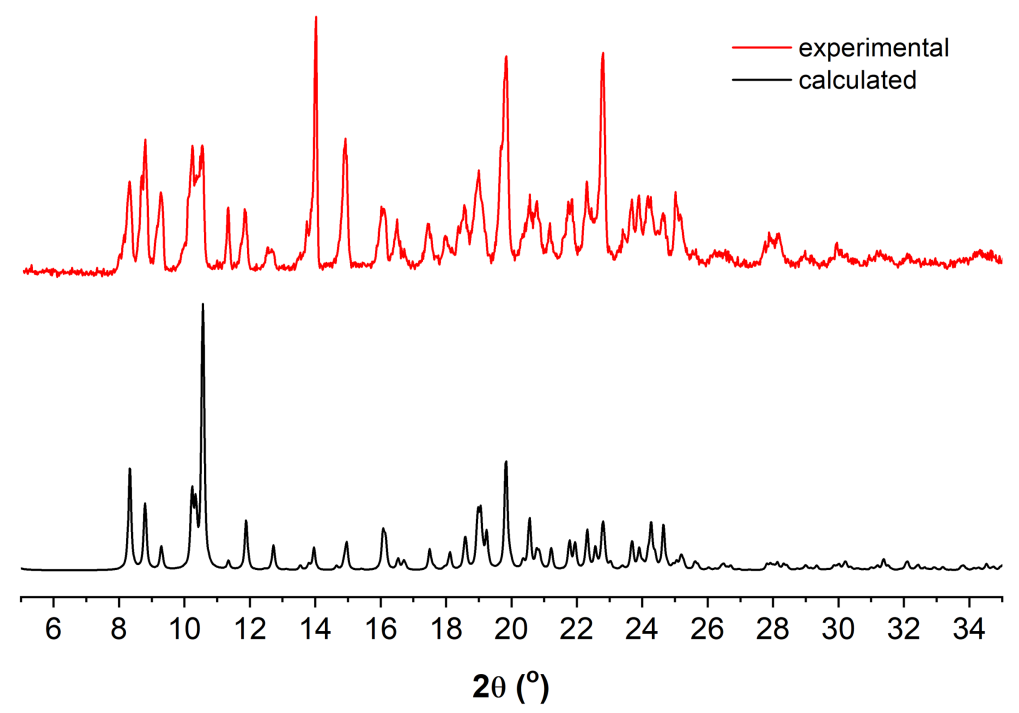

Figure S3. Measured (red) and calculated (black) powder X-ray diffraction patterns of $\left[\mathrm{Ni}_{0.2} \mathrm{Zn}_{0.8}\right]$. The simulated diffractogram was obtained using single crystal measurements of a crystal separated from $\left[\mathrm{Ni}_{0.2} \mathrm{Zn}_{0.8}\right]$. 


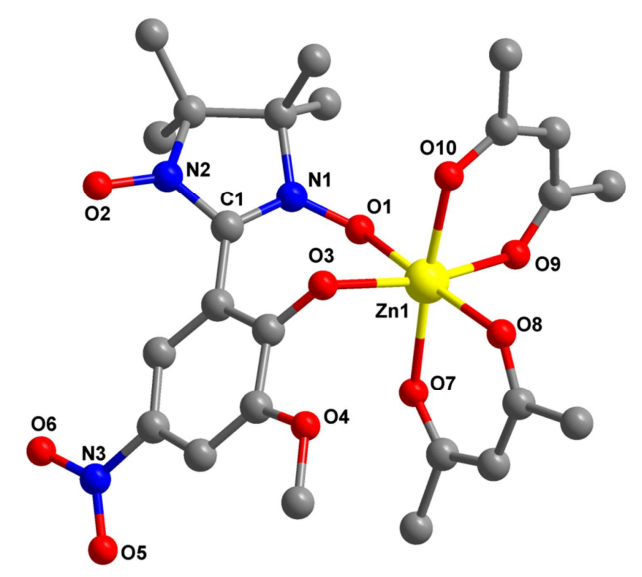

Figure S4. Crystal structure of complex 2. Hydrogen and fluorine atoms have been omitted for clarity.

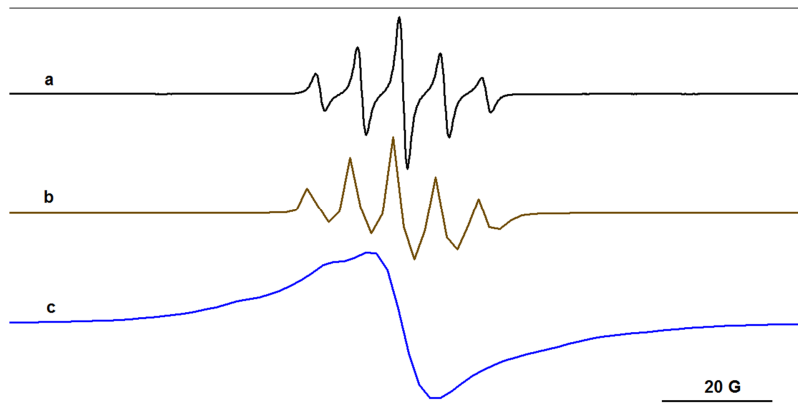

Figure S5. The EPR spectra (in $\mathrm{CH}_{2} \mathrm{Cl}_{2}$ ) of a) $\mathrm{HL}$ recorded at $293 \mathrm{~K}$, b) complex 2 recorded at $293 \mathrm{~K}, \mathrm{c}$ ) complex 2 recorded at $120 \mathrm{~K}$. 


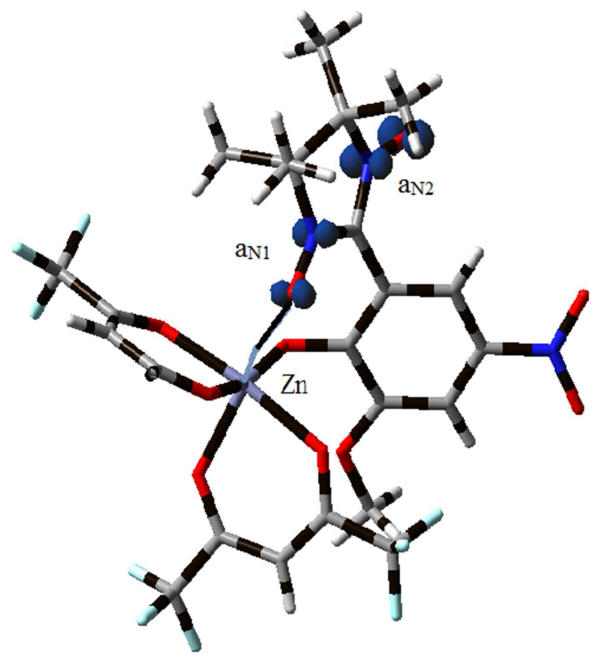

Figure S6. The isodensity $\left(0.04 \mathrm{e}^{\left.-/(a . u .)^{3}\right)}\right.$ surface of complex 2 calculated in DCM at the B3LYP/6-31g* level. 
Table S1. Crystallographic data, details of data collection and structure refinement parameters for $\left[\mathrm{Ni}_{0.2} \mathrm{Zn}_{0.8}\right]$.

\begin{tabular}{lc}
\hline Complex & {$\left[\mathbf{N i}_{0.2} \mathbf{Z n}_{0.8}\right]$} \\
\hline Empirical formula & $\mathrm{C}_{30} \mathrm{H}_{35} \mathrm{~N}_{4} \mathrm{Ni}_{0.2} \mathrm{Zn}_{0.8} \mathrm{O}_{10} \mathrm{~F}_{12}$ \\
Formula weight & 903.66 \\
Temperature (K) & 293.15 \\
Crystal system & Monoclinic \\
Space group & $P 2_{1} / \mathrm{c}$ \\
a $(\AA)$ & $20.3978(8)$ \\
$\mathrm{b}(\AA)$ & $9.5639(2)$ \\
$\mathrm{c}(\AA)$ & $21.5481(8)$ \\
$\alpha\left({ }^{\circ}\right)$ & 90 \\
$\beta\left({ }^{\circ}\right)$ & $111.215(4)$ \\
$\gamma\left({ }^{\circ}\right)$ & 90 \\
Volume $\left(\AA^{3}\right)$ & $3918.8(2)$ \\
$Z$ & 4 \\
$\mathrm{D}_{\mathrm{c}}\left(\mathrm{g} /\right.$ cm $\left.^{3}\right)$ & 1.532 \\
Absorption coefficient $\left(\mathrm{mm}^{-1}\right)$ & 0.714 \\
$F(000)$ & 1842.0 \\
$\theta$ range for data collection $\left({ }^{\circ}\right)$ & 2.142 to 30.746 \\
Index ranges & $-27 \leq h \leq 27,-10 \leq k \leq 13,-27 \leq l \leq 28$ \\
Reflections collected & 38210 \\
Independent reflections $\left[R_{\text {int }}\right]$ & $9784\left[R_{\text {int }}=0.0305\right]$ \\
Completeness to $\Theta$ full $(\%)$ & 99.99 \\
Data/restraints/parameters & $6784 / 24 / 657$ \\
Goodness of fit on $F^{2}$ & 0.938 \\
$R_{l}, w R_{2}[I>2 \sigma I]$ & $0.0402,0.1237$ \\
$R_{l}, w R_{2}($ all data) & $0.0680,0.1428$ \\
Largest diff. peak/hole $\left(\AA^{3}\right)$ & $0.26 /-0.21$ \\
\hline &
\end{tabular}

Table S2. Hfs constants for complexes 1 and $\mathbf{2}$ calculated at the uB3LYP level and three basis sets, TZVP,TZVP/EPR-III, 6-31g* considering the crystal geometry.

\begin{tabular}{|c|c|c|c|c|c|c|c|}
\hline & \multirow{2}{*}{$\begin{array}{c}\left|\mathrm{a}_{\mathrm{N}}\right| \\
(\mathrm{exp})\end{array}$} & \multicolumn{3}{|c|}{$\mathbf{T}$} & \multicolumn{3}{|c|}{$\mathbf{2}$} \\
\cline { 3 - 8 } & & TZVP & $\begin{array}{c}\text { TZVP, } \\
\text { EPR-III }\end{array}$ & $6-31 \mathrm{~g}^{*}$ & TZVP & $\begin{array}{c}\text { TZVP, } \\
\text { EPR-III }\end{array}$ & 6-31g* \\
\hline $\mathrm{a}_{\mathrm{N} 1}$ & 7.4 & -4.37 & -3.23 & -5.61 & 4.61 & 2.29 & 6.72 \\
\hline $\mathrm{a}_{\mathrm{N} 2}$ & 7.5 & -4.56 & -2.89 & -6.55 & 5.18 & 3.18 & 7.70 \\
\hline
\end{tabular}

